UDC 544.14:577.1

\title{
QUANTUM CHEMICAL MODELING OF ANTIOXIDANT ACTIVITY OF GLUTATHIONE INTERACTING WITH HYDROXYL- AND SUPEROXIDE ANION RADICALS
}

\author{
N. V. SOLOVYOVA 1 , T. Y. KUZNETSOVA ${ }^{2}$ \\ ${ }^{1}$ Higher State Medical Educational Institution of Ukraine Ukrainian \\ Medical Stomatological Academy, Poltava, Ukraine; \\ ${ }^{2} Y u$. Kondratyuk Poltava National Technical University, Ukraine; \\ e-mail:KZT7@yandex.ru
}

\begin{abstract}
Following the analysis of the results of quantum chemical simulation of interaction between a GSH molecule and oxygen radicals $\bullet \mathrm{OH}$ and $\bullet \mathrm{OO}^{-}$, it was found that it takes place through the acid-base mechanism, where GSH acts as a base towards $\bullet \mathrm{OH}$, and as an acid towards $\bullet \mathrm{OO}^{-}$. The results of quantum chemical calculations (electron density redistribution, energy characteristics) were correlated at the time of interaction of a GSH molecule with $\bullet \mathrm{OH}$ and $\bullet \mathrm{OO}^{-}$with a change of macroscopic parameters of the process of free oxygen radical electroreduction in the presence of GSH (potential and maximum current of reduction waves), which is a direct experimental macroscale evidence of results of the conducted nanoscale theoretical simulation.
\end{abstract}

Key word s: antioxidants, melatonin, hydroxyl radical, superoxide-anion-radical, glutathione.

$\mathrm{T}$ o decrease the negative effect of free oxygen radicals on a living organism practical medicine widely uses endogenous oxidants since they take part in the system of human organism protection from the aggressive action of free radicals, for example [1-3]. The lack of systematic investigations, especially at the molecular level, of antiradical activity of various antioxidants under their interaction with free radicals in biological systems not only determines availability of contradictory estimates in interpretation of the results of experimental regularities [4-7] but also creates difficulties in development of general ideas concerning the mechanisms of interaction of antioxidants with free radicals and purposeful approach to the control of these processes which are applied to medical practice $[8,9]$. The above said actualizes studying the antiradical activity of various antioxidants.

Interaction of antioxidants with free radicals is determined by the influence of the great number of various interrelated kinetic processes which stabilization is rather problematic even in the experiment conditions. Thus, it seem urgent to study efficiency of the influence of endogenous antioxidants by simulating the mechanism of their interaction with free radicals by the methods of quantum chemistry in combination with experimental ones, in particular, with electrochemical method that allows not only obtaining the substantiation of the positive effect of using the antioxidants but also establishing potential significance of these substances as medical remedies.

The work objective was investigation of antiradical properties of endogenous antioxidant glutathione $\left(\mathrm{C}_{10} \mathrm{H}_{17} \mathrm{~N}_{3} \mathrm{O}_{6} \mathrm{~S}\right)$ by simulation of the mechanism of its interaction with free radicals (hydroxyl radical $(\cdot \mathrm{OH})$ and superoxide-anion-radical $\left(\cdot \mathrm{OO}^{-}\right)$.

\section{Materials and Methods}

Human organism contains a nonenzymatic antioxidant system of cells protection from the influence of free radicals. The compounds with various properties appear as the system components. One of such compounds is glutathione (GSH) synthesized in each organism cell, but antiradical mechanism of its interaction with active oxygen forms at the microscopic level is not completely understood, except for certain results of macroscopic medical [11] and electrochemical [12] investigations which are unfortunately of phenomenological character and do not give a purposeful approach to such processes control.

One of the key active forms of oxygen is $\cdot \mathrm{OO}^{-}$, which is formed when adding one electron to oxygen molecule in the basic state and can be a source of - $\mathrm{OH}$ formation in human organism; it may be the strongest oxidizer among free oxygen radicals [13], thus $\bullet \mathrm{OH}$ and $\bullet \mathrm{OO}^{-}$can exist simultaneously and be 
used for studying their interaction with glutathione for simulation of its antioxidant activity. The above said has determined the choice of investigation objects.

Theoretical study of the mechanism of GSH interaction with $\cdot \mathrm{OO}^{-}$and $\bullet \mathrm{OH}$ is performed with the help of the program module GAMESS (version of March 27, 2007) and program module Firefly 8 by the most modern unempirical quantum chemical method in the basis $6-31 G^{* *}$ [14]. To calculate the solvent effect on properties of the systems under study the authors used the polarization continuum model PCM and set into motion the program CAUSSIAN 09 (D.01); the access to this model was kindly put at the authors' disposal by professor V. M. Gunko, Dr. sc. (chemistry), (O. O. Chuyko Institute of Chemistry of Surface, NAS of Ukraine).

Electrochemical investigations of simulation of GSH interaction with free oxygen radicals with the use of differential volt-ampermetry were conducted jointly with researchers of the Institute of Bioorganic Chemistry and Petroleum Chemistry of NAS of Ukraine. L-glutathione of the company SERVA, res. grad. was used for making the solution. The compounds were used without additional purification.

\section{Results and Discussion}

The establishing of the most active centers of glutathione molecule interaction with free oxygen radicals is of principal importance for the analysis of antiradical activity of GSH molecule. To search for the "attack directions" of glutathione molecules by free oxygen radicals the authors have calculated distribution of molecular electrostatic potential (MESP) in the radicals $\bullet \cdot \mathrm{OH}$ and $\cdot \mathrm{OO}^{-}$and in $\mathrm{GSH}$ molecule. As a result it was established that the MESP minimum localized near oxygen atom exists for $\bullet \mathrm{OH}$ and, on the contrary, its isotropic distribution is observed for ${ }^{\circ} \mathrm{OO}^{-}$. The obtained difference of such MESP distribution should obligatory be one of determining factors in establishing the mechanism of GSH interaction with radicals since they, having one uncoupled electrode in their composition, will "attack" the GSH molecule in directions with its positive values of MESP (near oxygen atoms).

To search for full energy minima corresponding to $\bullet \mathrm{OH}$ and $\cdot \mathrm{OO}^{-}$maxima with GSH molecule a detailed scanning of the surface of full interaction energy in the vicinity of " attack places" of GSH molecule was conducted. That was made by calculation of transition state of the reaction of interaction, with determining activation energy for each of the "attack directions" (Fig. 1), when changing the angle between the corresponding interatomic bonds of glutathione molecule and radicals and corresponding distances between reagents' atoms that has evidenced for availability of 17 minima of full energy for glutathione molecule, including the global one [15].

When GSH molecules interact with one $\cdot \mathrm{OO}^{-}$ at the point of global minimum of full interaction

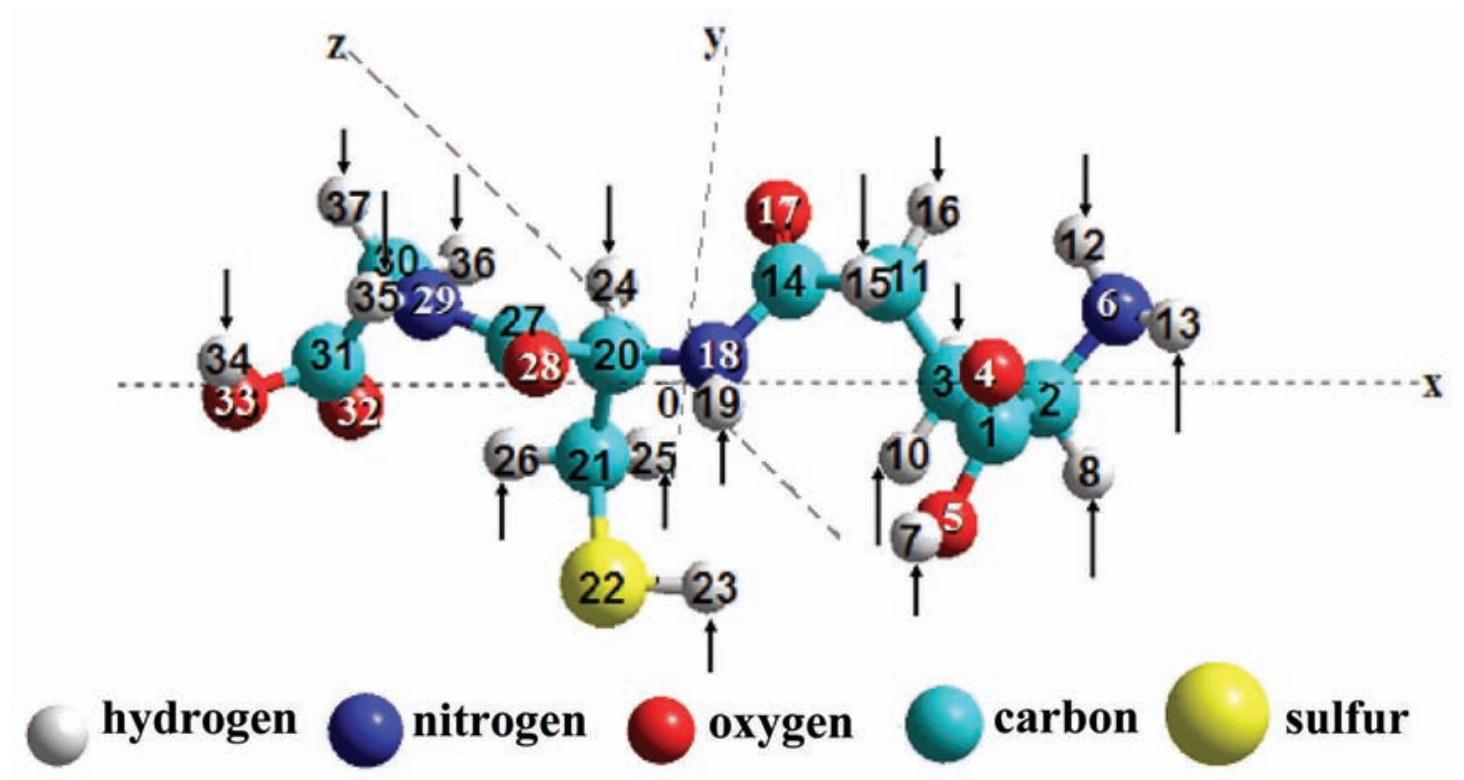

Fig. 1. "Attack directions" of different centers of GSH molecule with hydroxyl and superoxide-anion radicals (free enumeration of atoms; 0 - mass center of GSH molecule) 
energy there occurs redistribution of the charge of $0.702 \mathrm{e}$ with $\cdot \mathrm{OO}^{-}$to glutathione molecule through the atom of hydrogen $\mathrm{H}(23)$, indicating a possibility of efficient interaction of $\bullet^{-O^{-}}$with $\mathrm{GSH}$, with probable formation of stable complexes (Fig. 2).

Under analogous interaction with one $\cdot \mathrm{OH}$, on the contrary, there occurs an increase of electron density on oxygen atom of hydroxyl radical by 0.208 e, as a result the bond length $\mathrm{S}(22)-\mathrm{H}(23)$ increases in glutathione molecule from 0.132 to $0.317 \mathrm{~nm}$ that points to the possibility of this atom breaking off GSH molecule and its further attachment to $\cdot \mathrm{OH}$ with formation of water molecule (Fig. 3).

Simulation of the change of radicals $\left(\cdot \mathrm{OO}^{-}\right.$and - $\mathrm{OH})$ concentration in respect of antioxidant molecule has shown that the simultaneous interaction of five radicals in both cases with GSH molecule does

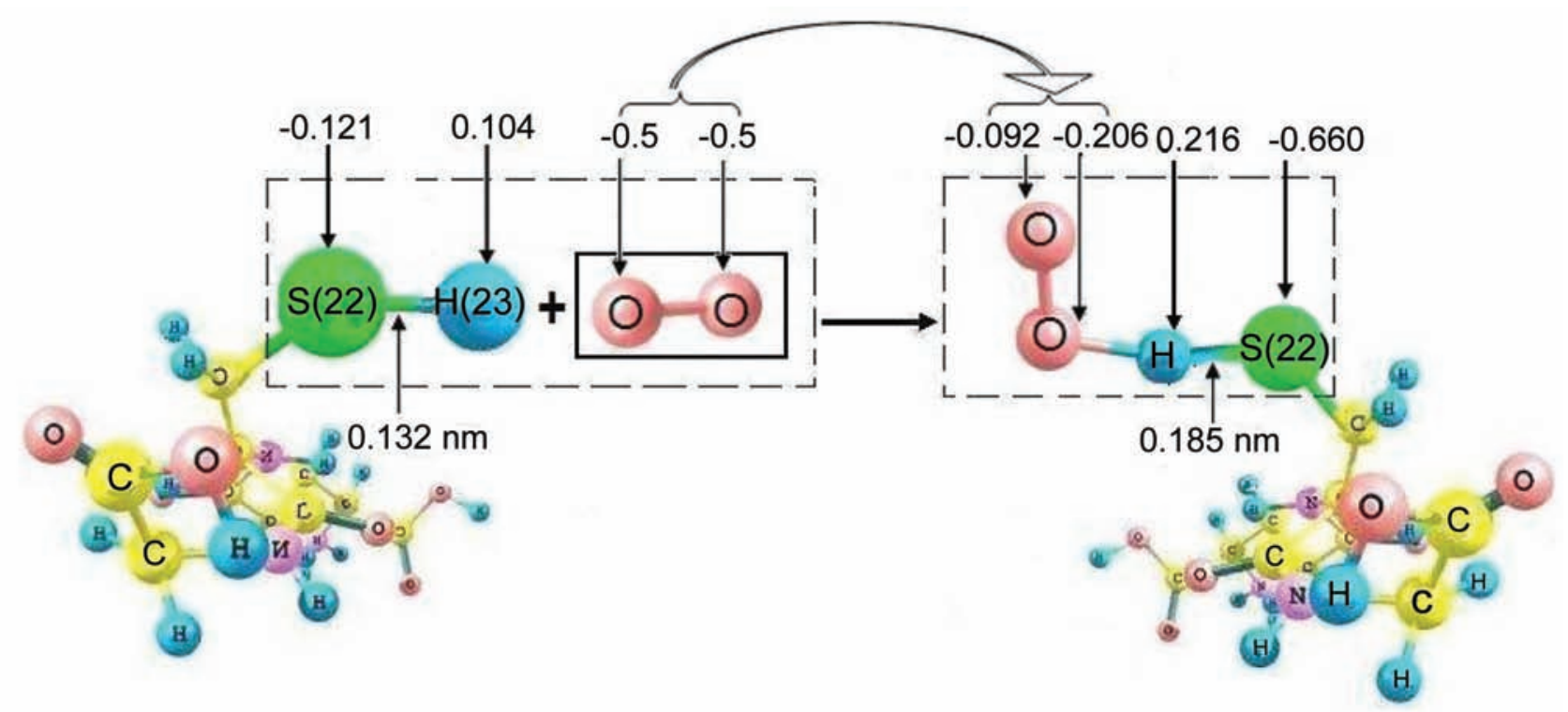

Fig. 2. Scheme of interaction of GSH molecule with $\cdot \mathrm{OO}^{-}$(arrows point to charges on atoms according to Lowdin)

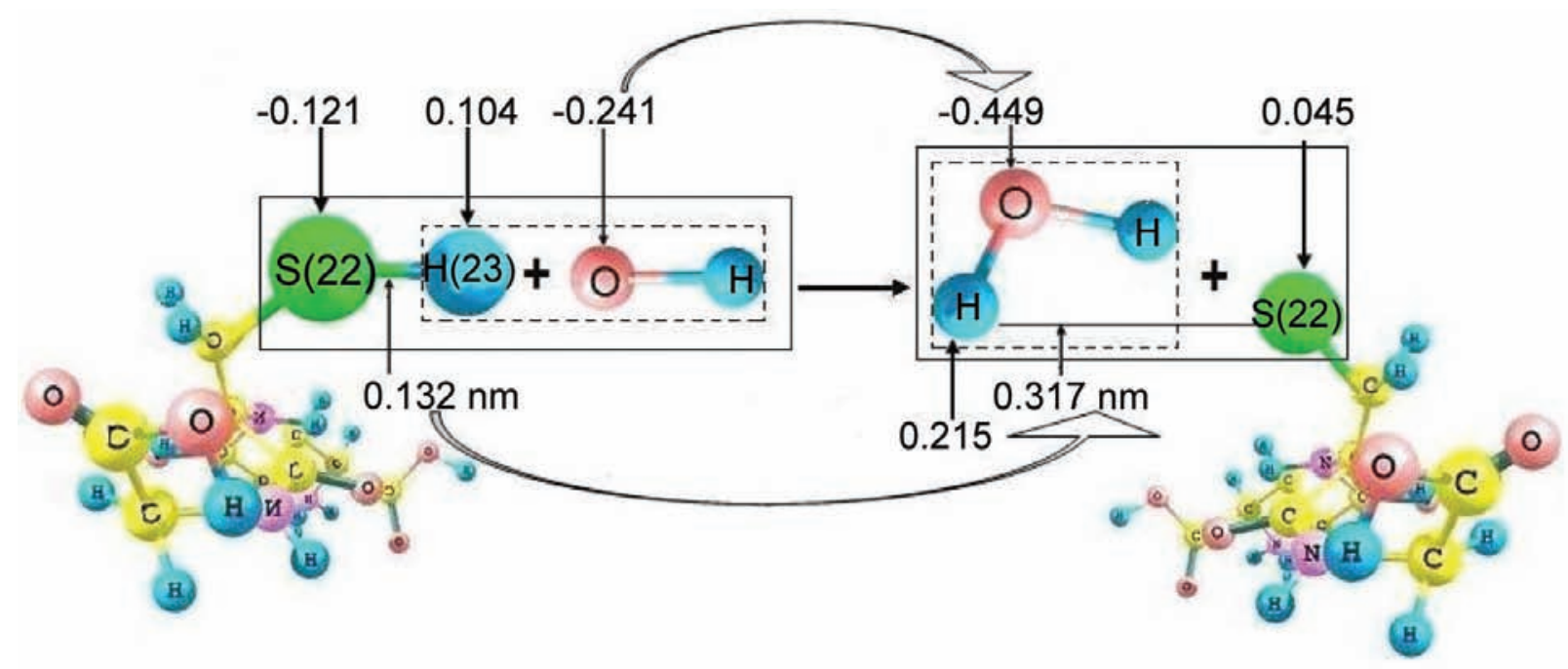

Fig. 3. Scheme of interaction of GSH molecule with $\bullet$ OH (arrows point to charges on atoms according to Lowdin) 
not change the character of redistribution of electron density for interaction with one radical as a whole, but makes it "softer".

Thus, the interaction of a molecule of studied antioxidant with free oxygen radicals initiates redistribution of electron density in the glutathione molecule in different directions (Fig. 4)

To bring the results of quantum-chemical modeling closer to real conditions of interaction of the antioxidant molecule with $\cdot \mathrm{OH}$ and $\cdot \mathrm{OO}^{-}$in human organism the authors performed simulation of water medium influence on the mechanism of GSH molecule interaction with free oxygen radicals in terms of Firefly 8 program. An analysis of results obtained has shown that the mechanism of electron density redistribution with allowance for water medium influence with dielectric constant $\varepsilon=78.355$ at $\mathrm{T}=298 \mathrm{~K}$ within the continual model of the solvent PCM for these interactions remains almost unchanged, that is confirmed by comparison of charges distribution according to Lowdin, corresponding distances in $\mathrm{GSH}, \cdot \mathrm{OH}, \cdot \mathrm{OO}^{-}$, as well as the values of activation energy of the reactions of GSH molecule interaction with $\bullet \mathrm{OH}$ and $\cdot \mathrm{OO}^{-}$(Table).

Thus, the quantum chemical simulation of glutathione molecule interaction with $\cdot \mathrm{OH}$ and $\cdot \mathrm{OO}^{-}$ has shown that the change of radicals concentration in respect of antioxidant and allowance for the influence of water medium do not practically influence redistribution of electron density of glutathione molecule and permit concluding that the studied reaction proceeds following the acid-base mechanism, under these conditions GSH appears as acid in respect of $\bullet \mathrm{OH}$ in accordance with the set scheme (Fig. 4).

To confirm the conclusions made by results of quantum-chemical simulation the authors performed electrochemical investigations of GSH interaction with free oxygen radicals in physiologic water so-

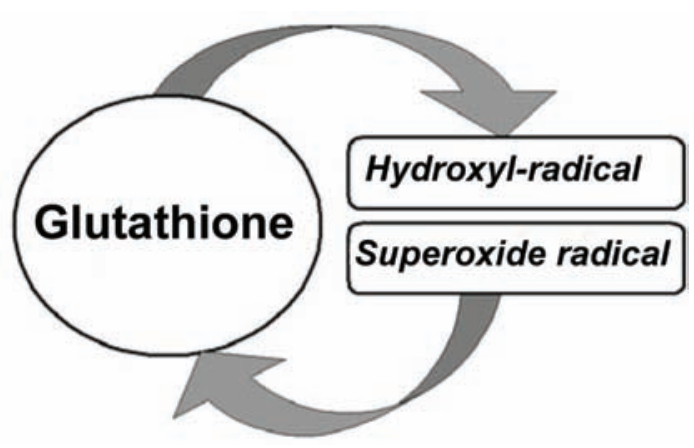

Fig. 4. Scheme of redistribution of electron density of GSH molecule as a result of interaction with radicals

lution by electrochemical generation of free oxygen radicals in the presence of antioxidant [16].

Differential volt-ampere curves of reduction of free oxygen radicals which characterize reactions (1-3) analogous to those proceeding in biosystems in the process of respiration, metabolism, oxygen stress:

wave $\mathrm{I}(\mathrm{E}=-0.2 \mathrm{~B}) \cdot \mathrm{OH}+\mathrm{e}^{-} \rightarrow \mathrm{OH}^{-}$,

wave II $(\mathrm{E}=-0.7 \mathrm{~B}) \mathrm{O} 2+1 \mathrm{e}^{-} \rightarrow \cdot \mathrm{OO}^{-}$,

$\cdot \mathrm{OO}^{-}+1 \mathrm{e}^{-}+2 \mathrm{H}^{+} \rightarrow \mathrm{H}_{2} \mathrm{O}_{2}$,

wave III $(\mathrm{E}=-1.1 \mathrm{~B}) \mathrm{H}_{2} \mathrm{O}_{2}+\mathrm{e}^{-} \rightarrow \mathrm{OH}^{-}+\cdot \mathrm{OH}$,

were taken on the background of $0.1 \mathrm{M}$ solution of $\mathrm{NaCl}$ in water (physiologic solution) with following titration of background electrolyte with GSH additions of various concentration.

When adding GSH additives of different concentration (2-6) to background solution, the authors observed the change of positions of reduction waves (Fig. 5). In so doing the reduction potential of the first wave did not change, that points to reduction of electrochemically active particles (EAP) similar by type and shape. The increase of concentrations of GSH additions leads to essential decrease of the

Comparative distribution of charges $q$ according to Lowdin, distances $R$ and activation energies $E_{a}$ under GSH molecule interaction with free oxygen radicals at a point of global minimum

\begin{tabular}{|c|c|c|c|c|c|c|c|c|}
\hline \multirow{2}{*}{\multicolumn{3}{|c|}{ Interaction }} & \multicolumn{2}{|c|}{$\mathrm{R}, \mathrm{nm}$} & \multicolumn{3}{|c|}{ q, a.o. } & \multirow{3}{*}{$\frac{E_{a}, k J / m o l}{101}$} \\
\hline & & & $\mathrm{S}(22)-\mathrm{H}(23)$ & $\mathrm{O}-\mathrm{H}(23)$ & $S(22)$ & $\mathrm{H}(23)$ & O* & \\
\hline \multirow{4}{*}{ GSH } & \multirow{2}{*}{$\cdot \mathrm{OH}$} & Without PCM & 0.317 & 0.095 & 0.045 & 0.215 & -0.449 & \\
\hline & & PCM & 0.268 & 0.094 & 0.036 & 0.222 & -0.465 & 100 \\
\hline & \multirow{2}{*}{$\cdot \mathrm{OO}^{-}$} & Without PCM & 0.185 & 0.098 & -0.660 & 0.216 & -0.206 & 17 \\
\hline & & PCM & 0.195 & 0.096 & -0.731 & 0.211 & -0.187 & 7 \\
\hline
\end{tabular}

*Indicated atom of radical which directly interacts with atom H(23) of GSH molecule. 
boundary current of the first waves on curves at the expense of chemical reaction of $\cdot \mathrm{OH}$ inhibition in the solution volume phase by the scheme (4):

$\mathrm{C}_{10} \mathrm{H}_{17} \mathrm{~N}_{3} \mathrm{O}_{6} \mathrm{~S}+\cdot \mathrm{OH} \rightarrow \cdot \mathrm{C}_{10} \mathrm{H}_{16} \mathrm{~N}_{3} \mathrm{O}_{6} \mathrm{~S}+\mathrm{H}_{2} \mathrm{O}$,

that points to the decrease of $\bullet \mathrm{OH}$ amount in analogy with the processes occurring in human organism under the effect of GSH.

Further reduction of $\bullet \mathrm{OH}$, which concentration will decrease as a result of the reaction (4) and under introduction of addition GSH will be observed at unchanged potential (0.2 B) on the electrode according to the following reaction:

$$
\cdot \mathrm{OH}+1 \overline{\mathrm{e}} \rightarrow \mathrm{OH}^{-} \text {. }
$$

We explained earlier the cathode shift of the second wave of reduction by purely phenomenological complex formation of glutathione with oxygen [16], since it is impossible to analyze it basing only on electrochemical approach, as it was in the case with the first wave of reduction. That is why we have made a comparative quantum-chemical estimation of activation barriers of a single-electron reduction according to (2) for isolated superoxide-anion-radical and its complexes with glutathione which has shown that the calculated activation barrier for "isolated" molecule $\cdot \mathrm{OO}^{-}$is $572.5 \mathrm{~kJ} / \mathrm{mol}$, and for the complex $\left\{\mathrm{GSH} . . \cdot \mathrm{OO}^{-}\right\}-425.2 \mathrm{~kJ} / \mathrm{mol}$ at a single-electron reduction that explains the cathode shift of the second wave of $\bullet \mathrm{OO}^{-}$reduction with an increase of $\mathrm{GSH}$ concentration in the direction of a decrease of the reduction potential value and points to the process of reduction of EAP different in their type and shape at the expense of complex formation which simplifies the process of electric reduction in contrast to (5).

Thus, on the basis of analysis of quantumchemical simulation results the authors have established the most probable active centers of GSH molecule interaction with free oxygen radicals which correspond to the deepest minima of full interaction energy. The mechanism of glutathione molecule interaction with $\bullet \mathrm{OH}$ and $\bullet \mathrm{OO}^{-}$has been investigated. It has shown that the reaction between antioxidant and radicals proceeded according to acid-base mechanism, where GSH acts as a base towards $\bullet \mathrm{OH}$, and as an acid towards $\bullet^{\mathrm{OO}^{-}}$. Correlation of the obtained results of quantum-chemical calculations (redistribution of electron density, energy characteristics) under the interaction of glutathione molecule with free oxygen radicals with the change of macroscopic parameters of electric reduction of oxygen free radicals in the presence of glutathione (potential

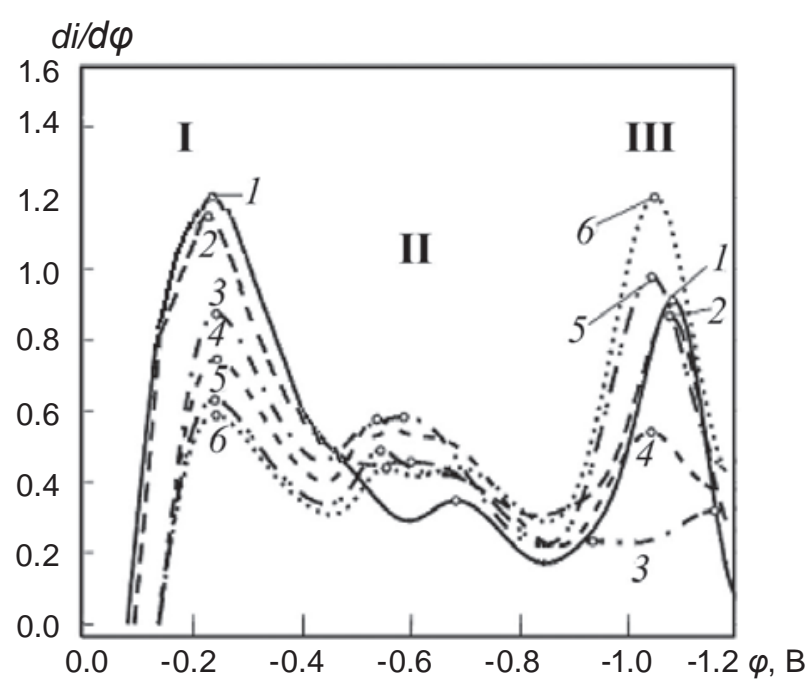

Fig. 5. Differential volt-amperograms of reduction of free oxygen radicals on a copper cathode against a background of $0.1 \mathrm{M} \mathrm{NaCl}$ in water (1) in the presence if various concentrations of GSH $(T=298 \mathrm{~K}): 2-0.24 ; 3-0.47 ; 4-0.74 ; 5-0.91$; $6-1.1 \cdot 10^{3} \mathrm{M} / \mathrm{ml}$

and boundary current of reduction waves). That is a direct experimental confirmation on the level of results of theoretical simulation conducted on the nanolevel.

\section{КВАНТОВОХІМІЧНЕ \\ МОДЕЛЮВАННЯ \\ АНТИОКСИДАНТНОЇ АКТИВНОСТІ \\ ГЛУТАТІОНУ ЗА ВЗАЕМОДІї \\ З ГІДРОКСИЛ- І СУПЕРОКСИД- АНІОН-РАДИКАЛАМИ}

\section{Н. В. Соловйова ${ }^{1}$, Т. Ю. Кузнечова ${ }^{2}$}

${ }^{1}$ ВДНЗ України «Українська медична стоматологічна академія», Полтава, Україна;

${ }^{2}$ Полтавський національний технічний університет ім. Ю. Кондратюка, Україна; e-mail: KZT7@yandex.ru

На основі аналізу результатів квантовохімічного моделювання взаємодії молекули GSH із радикалами кисню $\cdot \mathrm{OH}$ i $\cdot \mathrm{OO}^{-}$ встановлено, що цей процес відбувається за кислотно-основним механізмом, причому GSH по відношенню до • OH виступає як основа, а по відношенню до $\cdot \mathrm{OO}^{-}-$як кислота. Проведено кореляцію одержаних результатів квантовохімічних розрахунків (перерозподіл електронної густини, енергетичні характери- 
стики) за взаємодії молекули $\mathrm{GSH}$ із $\bullet \mathrm{OH}^{\mathrm{i}} \cdot \mathrm{OO}^{-}$ зі зміною макроскопічних параметрів процесу електровідновлення вільних радикалів кисню у присутності GSH (потенціал та граничний струм хвиль відновлення), що є прямим експериментальним підтвердженням на макрорівні результатів проведеного на нанорівні теоретичного моделювання.

К л юч о в с лов а: антиоксидант, гідроксил-радикал, супероксид-аніон-радикал, глутатіон.

\section{КВАНТОВОХИМИЧЕСКОЕ МОДЕЛИРОВАНИЕ \\ АНТИОКСИДАНТНОЙ \\ АКТИВНОСТИ ГЛУТАТИОНА ПРИ ВЗАИМОДЕЙСТВИИ С ГИДРОКСИЛ- И СУПЕРОКСИД-АНИОН- РАДИКАЛАМИ}

\section{Н. В. Соловьева ${ }^{1}$, Т. Ю. Кузнеиова ${ }^{2}$}

${ }^{1}$ ВГУЗ Украины «Украинская медицинская стоматологическая академия», Полтава, Украина;

${ }^{2}$ Полтавский национальный технический университет им. Ю. Кондратюка, Украина; e-mail: KZT7@yandex.ru

На основании анализа результатов квантовохимического моделирования взаимодействия молекулы GSH с радикалами кислорода $\cdot \mathrm{OH}$ и - $\mathrm{OO}^{-}$установлено, что этот процесс происходит по кислотно-основному механизму, причем GSH в отношении $\cdot \mathrm{OH}$ выступает как основание, а по отношению к $\cdot \mathrm{OO}^{-}-$как кислота. Проведена корреляция полученных результатов квантовохимических расчетов (перераспределение электронной плотности, энергетические характеристики) при взаимодействии молекулы GSH $\mathrm{c} \cdot \mathrm{OH}$ и $\cdot \mathrm{OO}^{-}$с изменением макроскопических параметров процесса электровосстановления свободных радикалов кислорода в присутствии GSH (потенциал и предельный ток волн восстановления), что является прямым экспериментальным подтверждением на макроуровне результатов проведенного на наноуровне теоретического моделирования.

К л ю че вы е с ло в а: антиоксиданты, мелатонин, гидроксил-радикал, супероксид-анион-радикал, глутатион.

\section{References}

1. Chesnokova N. P., Ponukalyna E. V., Byzenkova M. N. Molecular-cellular mechanisms of inactivation of free radicals in biological systems. Adv. Curr. Nat. Sci. 2006;(7):29-36. (In Russian).

2. Belenychev I. F., Gubskiy Y. I., Levitsky E. L. Regulation of antioxidant homeostasis and detoxification system of the body of the hormone melatonin. The role of melatonin-dependent receptors in the realization of this function. Mod. Probl. Toxicol. 2003;(2):2-16. (In Russian).

3. Boveris A. Determination of the production of superoxide radicals and hydrogen peroxide in mitochondria. Methods Enzymol. 1984;105:429435.

4. Mahyn D. V., Izmailov D. Yu., Popov I. N., Vladimirov Yu. A. Photochemilumenescence as a method of studying the antioxidant activity in biological systems. Mathematical modeling. Probl. Med. Chem. 2000;46(4):61-66. (In Russian).

5. Ehlenfeldt M. K., Prior R. L. Oxygen radical absorbance capacity (ORAC) and phenolic and anthocyanin concentrations in fruit and leaf tissues of highbush blueberry. J. Agric. Food Chem. 2001;(49):2222-2227.

6. Korotkova E. I., Karbainov Yu. A., Shevchuk A. V. Study of antioxidant properties by voltammetry. J. Electroanal. Chem. 2002;508(1):56-60.

7. Korotkova E. I., Karbainov Y. A., Avramchik O. A. Investigation of antioxidant and catalytic properties of some biologically active substances by voltammetry. Anal. Bioanal. Chem. 2003;375(1-3):465-468.

8. Bachuryn S. O. Medico-chemical approaches directed search of drugs for the treatment and prevention of Alzheimer's disease. Probl. Med. Chem. 2001;47(2):155-197. (In Russian).

9. Prutz W. A., Butler J., Land E. J. The glutathione free radical equilibrium mediating electron transfer to $\mathrm{Fe}(\mathrm{III})$ - cytochrome. J. Biophys. Chem. 1994;49(2):101-111.

10. Kulinskiy V. I., Kolesnychenko V. I. The biological role of glutathione. Uspekhi Sovremennoi Biologii. 1990;51(1(4)):20-33. (In Russian).

11. Anderson M. E. Glutathione: an overview of biosynthesis and modulation. Chem. Biol. Interact. 1998;111-112:1-14. 
12. Shapoval G. S., Myronyuk I. E., Thunder V. F., Kruglyak O. S. Electrochemical modeling of redox-reaction of glutathione. J. Gen. Chem. 2008;78(12):2040-2044. (In Russian).

13. Kolisnyk M. I., Colisnic H. V., Niedziolka J., Vlizlo V. V. Oxygen active forms that their rolein cells metabolism. Anim. Biol. 2009;11(12):59-67. (In Ukrainian).

14. Granovsky A. A. Firefly and PC GAMESS / Firefly version 8.0.1. [Electronic resource]. Access mode //http://classic.chem.msu.su /gran/ games/forum/ discussion.html.
15. Kuznetsova T. Y., Solovyova N. V. Simulation of antioxidant properties of melatonin and glutathione in contact with hydroxy radicals. Urgent Probl. Mod. Med.: News Ukr. Med. Stomat. Acad. 2012;12(1-2(37-38)):189-193. (In Russian).

16. Shapoval G. S., Kruglyak O. S., Kuznetsova T. Yu., Soloviev V. V., Nestyuk N. V. Electrocatalytic oxidation of natural endogenous antioxidants. Catal. Petrochem. 2009;(17):31-38. (In Russian).

Отримано 07.07.2014 